\title{
Is the Implementation of Good Corporate Governance Principles Capable of Improving Company Performance? (Study at Sharia Commercial Banks in Bandung City, Indonesia)
}

\author{
Rini Lestari ${ }^{*}$, Diamonalisa Sofianty ${ }^{2}$, Ririn Srikuntorini ${ }^{3}$ \\ ${ }^{1}$ Faculty of Economics and Business, Accounting Study Program, UniversitasIslam Bandung \\ ${ }^{2}$ Faculty of Economics and Business, Accounting Study Program,Universitas Islam Bandung \\ ${ }^{3}$ Faculty of Economics and Business, Accounting Study Program,Universitas Islam Bandung
}

\begin{abstract}
The implementation of Good Corporate Governance (GCG) principles which includes: transparency, accountability, independence, responsibility and fairness are expected to improve company performance. Various problems that are related to the weak implementation of GCG principles have led to a decline in company performance. The purpose of this study is to analyze how far the implementation of GCG principles and how the company performance is measured by using Balanced Scorecard (BSC) method at Sharia Commercial Banks in Bandung City and then to analyze how the implementation of GCG principles is able to improve the company performance which is measured by using BSC method. In this study, the research method is descriptive with a qualitative approach. This study was conducted on nine Sharia Commercial Banks in Bandung City. Data collection techniques were carried out by distributing questionnaires to 45 operational managers at Sharia Commercial Bank in Bandung City and by interviews. The sampling technique is non probability sampling with the type of convenience sampling. The study results indicate that the implementation of GCG principles in Sharia Commercial Banks in Bandung City is very good. The company performance in Sharia Commercial Banks in Bandung City which are measured using BSC method is in very good category.Furthermore, the implementation of GCG principles in Sharia Commercial Banks in Bandung City is able to improve the company performance which is measured by using BSC method, as it is evidenced by one of them when Sharia Commercial Banks apply the responsibility principle in their operational activities, the level of customer trust will increase. With the increasing of customer trust, it will result in a higher level of financial return as an indicator in the increasing of company performance as it is measured by BSC method.
\end{abstract}

Keywords: good corporate governance principles, company performance and balanced scorecard.

DOI: $10.7176 / \mathrm{EJBM} / 11-6-10$

\section{Introduction}

The monetary crisis in Indonesia which was occurred around 1997-1998 impacted the business of banking institutions, resulting in a decrease in the level of public trust in the institution. Zarkasyi (2008) explains that "efforts to restore trust to the banking world through restructuring and recapitalization can only have a long-term impact if it is accompanied by the implementation of Good Corporate Governance principles". The good/bad implementation of GCG principles has an influence on the good/bad performance of the company, especially the sharia commercial banks (Galileoni \& Lestari, 2017). The performance of sharia commercial banks can be measured through financial performance, one of which is the Return on Assets (ROA) level. The following data is the performance of sharia public banks based on ROA levels starting from 2014 s.d 2017 (OJK, 2017):

Table 1.1

Sharia Commercial Bank Performance Based on ROA Level

\begin{tabular}{|l|l|l|l|l|}
\hline Remarks & $\mathbf{2 0 1 4}$ & $\mathbf{2 0 1 5}$ & $\mathbf{2 0 1 6}$ & $\mathbf{2 0 1 7}$ \\
\hline Return On Asset & 0.41 & 0.49 & 0.63 & 0.63 \\
\hline
\end{tabular}

Source: OJK (2017)

The above table shows that the financial performance of sharia commercial banks as it is measured by ROA level since 2014 s.d 2017 has increased, however the ROA level is still far from the ideal value or the best 
value of 1.00 or 100 percent. Based on the ROI level in table 1.1 above, the performance of sharia commercial banks in Indonesia in the period of 2014 s.d 2017 cannot be said to be good. The poor financial performance of sharia commercial banks can be caused by the weak implementation of GCG principles. The problems related to the weak implementation of GCG principles at sharia banks have occurred in PT Bank SyariahMandiri (BSM) as it is disclosed by the Indonesian Anti-Corruption Society (MAKI, 2018) that PT BSM channeled fictitious financing worth 1.1 trillion. It was fictitious because the financing from debtors is not used according to the proposal when the money is disbursed.There is even an indication that disbursed financing is used for personal purposes. From this problem, it has been alleged that the decision-making process for financing disbursement in sharia banks has ignored the responsibility principle in the implementation of GCG. From the poor implementation of GCG principles in sharia banks, it can lead to a decline in public distrust so that the performance of sharia public banks has become worse due to losses, due to irregularities in financing distribution.

Financial Services Authority/OtoritasJasaKeuangan as a regulator has regulated the implementation of GCG in sharia banking institutions in PJOK No.4/POJK.03/2015 concerning Implementation of Good Corporate Governance for Sharia Commercial Banks and Sharia Business Units Article 2 paragraph (1). The implementation of GCG principles in sharia banking institutions should be carried out in every bank activity so as to improve the performance of sharia banking institutions. However, in reality, the implementation of GCG principles in sharia banking, including sharia commercial banks, continues to experience various obstacles and detentions, as it was previously explained above.

\subsection{Problem Formulation}

Based on the description in the research background, the problems can be formulated as follow:

1) How the Implementation of Good Corporate Governance (GCG) Principles in Sharia Commercial Banks in Bandung City.

2) How the Company Performance that is measured by using Balanced Score Card (BSC) method in Sharia Commercial Banks in Bandung City.

3) How far the relations between the implementation of GCG principles and company performance as it is measured by BSC method on Sharia Commercial Banks in Bandung City.

\section{Literature Review}

\subsection{Implementation of Good Corporate Governance (GCG) Principles}

The implementation of Good Corporate Governance (GCG) principles is the implementation in the principles of transparency, accountability, responsibility, independence and fairness in the organization management process for determining the company goals, achievements, and performance appraisal (Zarkasyi, 2008: 36). Bank Indonesia Regulation No.8/4/PBI/2009 and POJK No.4/POJK.03/2015, the dimensions in the implementation of good corporate governance principles can be seen in the following table: 
Table 1

Good Corporate Governance Dimensions

\begin{tabular}{|c|c|c|}
\hline No & Dimensions & Indicators \\
\hline 1 & Transparency & $\begin{array}{l}\text { 1. Disclosing financial and non-financial information in a timely manner } \\
\text { 2. Involving the controlling shareholders, executive officers and risk } \\
\text { managers } \\
\text { 3. The existence in the system of supervision and internal control } \\
\text { 4. The existence of compliance status, system and implementation of } \\
\text { GCG } \\
\text { 5. The existence of business objectives and company strategies } \\
\text { 6. Information which is related to the vision and mission of the company }\end{array}$ \\
\hline 2 & Accountability & $\begin{array}{l}\text { 1. The existence in the responsibility of the organization organ which is } \\
\text { in line with the vision and mission of the bank } \\
\text { 2. The responsibility of the organization organ is in line with the goals } \\
\text { and strategies of the bank } \\
\text { 3. Organization organs have the competencies in accordance with their } \\
\text { responsibilities }\end{array}$ \\
\hline 3 & Responsibility & $\begin{array}{l}\text { 1. Holding on to the precautionary principle } \\
\text { 2. Carrying out social responsibility }\end{array}$ \\
\hline 4 & Indenpendency & $\begin{array}{l}\text { 1. Avoiding unnatural domination by stakeholders } \\
\text { 2. Being not influenced by an unilateral interests and free from conflicts } \\
\text { of interest } \\
\text { 3. Objective decisions and free from pressure from any party }\end{array}$ \\
\hline 5 & Fairness & $\begin{array}{l}\text { 1. Paying attention to the interests of all stakeholders based on the } \\
\text { principle of equality and fairness } \\
\text { 2. Providing opportunities for stakeholders to convey input and opinions } \\
\text { for the company } \\
\text { 3. Stakeholders have access to information in accordance with openness } \\
\text { principle }\end{array}$ \\
\hline
\end{tabular}

\subsection{Company Performance}

Kaplan \&Negel (2004: 241) states that: "company performance measurement system that comprehensively measures both financial and non-financial aspects is called Balanced Scorecard method. Balanced Scorecard measures the company performance through four aspects or four perspectives, namely: financial perspective, customer perspective, internal business process perspective and learning and growth perspective." In measuring the company performance through financial perspective, it can be shown from the increasing of ROI, the increasing of sales revenue and the decreasing of company operating costs. To measure the company performance through the customer perspective, it can be assessed from the increasing number of customers, the increasing of new products and services and the increasing of the value that is received by customers. In measuring the company performance through internal business processes perspective, it can be shown from the existence of beneficial process improvements and the reduceing of non-value-added activities. Furthermore, in measuring the company performance through growth and learning perspective, it can be assessed from the higher productivity and commitment of each member of the organization, the better quality of the organization, the better quality of infrastructure and facilities and the better quality of information management systems. 


\subsection{Framework}

Implementing Good Corporate Governance (GCG) principles to the maximum extent can lead to better performance. This can be demonstrated if a company, especially Sharia commercial bank, carries out the principle of responsibility, the bank will carry out its activities very carefully and will not harm the customer, so that the trust of customer can always be improved. If the trust of customer increases, the performance of sharia commercial banks can also increase through increasing the amount of funding which is received as productive assets and distribution in the form of financing resulting in mutually beneficial results between the two parties. As the results of previous studies which are conducted by Lestari $(2013,2015)$ and Galileoni\& Lestari (2017) show that the implementation of good corporate governance (GCG) if it is implemented properly, it can control management and risk in the organization so that it can influencethe organization performance.

Several other studies that show the better implementation of GCG can produce better company performance are (Fadilah, 2011; Yesser, et al., 2011; Tornyeva\&Wereko, 2012; Adi, et al., 2013 Aggarwal, 2013; Makki\&Lodhi, 2013; Fidanoski, et al., 2013; Todorovic, 2013; El Gabasi, et al., 2014; Mudashiru, et al., 2014; Siallagan\&Januarti, 2014; Setiyawati\&Nengzih, 2014; Lestari, 2013 \& 2015 ; Ahmed \&Hamdan, 2015; Halimatusadiah, et al., 2015; Mustapa, et al., 2015; Kasim, 2015; Sanchia\& Zen, 2015; Wagana\&Kananja, 2015; Pasic, et al., 2016; Ramli, et al., 2016; Susanto, 2016; Alam, et al., 2017; Alobaidi, et al., 2017; Buallay, et al., 2017; Halim, et al., 2017; Khazalia, 2017; Galileoni\& Lestari, 2017 ; Uyar, et al., 2017).

Based on the description in the framework above, it can be assumed that: The implementation of Good Corporate Governance (GCG) principles is related to company performance as it is measured by BSC.

\section{Methods}

The research method in this study is descriptive with a qualitative approach. This research is conducted on Sharia banking institutions, especially Sharia Commercial Banks in Bandung City. Data collection is a "systematic and standard procedure to obtain the data that is used" (Nazir, 2011: 174). Data collection is a systematic and standard procedure to obtain the data used (Nazir, 20011: 174). Data collection techniques in this study are questionnaires and interviews. Questionnaires are distributed to 45 operational managers at Sharia commercial Bank in Bandung city. Furthermore, interviews are conducted with approximately 15 operational managers in several Sharia Commercial Banks in Bandung city. The sampling technique is non probability sampling with the type of convenience sampling.

Based on data from OJK (2017), there are 12 Sharia Commercial Banks that operate in Bandung city in 2016-2107 periods. The 12 Islamic Commercial Banks are used as target populations. Of the 12 Sharia Commercial Banks, only 9 Sharia Commercial Banks are willing to fill out the questionnaires and conduct the interviews, so there are only 9 Sharia Commercial Banks.

The stages of data analysis that are performed to answer the formulation of the problem are: analyzing the results of the answers/responses of respondents to the questions/statements for the implementation of GCG principles, analyzing the results of respondent responses to the statement of company performance as it is measured by BSC and then analyzing each dimension and indicator in both variables to see the extent of the relation between the implementation of GCG principles and company performance as it is measured by BSC. 


\section{Results and Discussion}

\subsection{Implementation of Good Corporate Governance (GCG) Principles in Sharia Commercial Banks in Bandung City}

The implementation of Good Corporate Governance (GCG) principles is measured through five dimensions and each dimension consists of two to six indicators, then overall indicator is operationalized into seventeen statements. The following is the recapitulation of the average score of respondent assessment of each variable dimension of the implementation of GCG principles.

\section{Table 4.1}

Recapitulation of the average answer score to variables of the implementation of GCG principles

\begin{tabular}{|c|l|c|c|}
\hline No. & \multicolumn{1}{|c|}{ Dimension } & Average score & Category \\
\hline 1 & Transparency & 4.72 & Very Good \\
\hline 2 & Accountability & 4.83 & Very Good \\
\hline 3 & Responsibility & 4.54 & Very Good \\
\hline 4 & Independency & 4.39 & Very Good \\
\hline 5 & Fairness & 4.72 & Very Good \\
\hline & \multicolumn{1}{|c|}{ Good Corporate Governance } & $\mathbf{4 . 6 4}$ & Very Good \\
\hline & Gap of Ideal Score & $\mathbf{0 . 3 6}$ & \\
\hline
\end{tabular}

Based on the average of respondent response score, the implementation of GCG principles in Sharia Commercial Banks in Bandung City is in very good category. Furthermore, when it is viewed based on dimensions: Transparency, Accountability, Responsibility, Independence, and Fairness in Sharia Commercial Banks in Bandung City are included in very good category. Although the total average score for the implementation of GCG principles is in very good category, there is still a gap from the ideal score of 0.36 or equivalent to $7.2 \%$. A gap of $7.2 \%$ is a form of quantification of the ideal condition (which is expected) that is if all respondents answered the scale 5. From an average score of 4.64 for the implementation of the GCG principles, it is known that the minimum average is 4.39 , while the maximum average is at number 4.83. It is known that the smallest minimum average value in the implementation of the GCG principles lies in independency dimension, so that it is hoped that there will be an effort to improve the implementation of independency principle to improve the overall implementation of GCG principles.

\subsection{Company performance as it is measured by Balanced Score Card (BSC) method in ShariaCommercial Banks in Bandung City}

Company performance by using BSC method is measured through four dimensions and each dimension consists of two to four indicators, then overall indicator is operationalized into twelve statements. The following is the recapitulation of the average score of respondent assessment in each dimension of the company performance variables.

Table 4.2

Average recapitulation of answer scores on Company Performance variable

\begin{tabular}{|c|l|c|c|}
\hline No. & Dimension & Average score & Category \\
\hline 1 & Financial Perspective & 4.65 & Very Good \\
\hline 2 & Customer Perspective & 4.60 & Very Good \\
\hline 3 & Internal Business Process Perspective & 4.76 & Very Good \\
\hline 4 & Growth and Learning Perspectives & 4.38 & Very Good \\
\hline & Company Performance & $\mathbf{4 . 5 9 7 5}$ & Very Good \\
\hline & Gap of Ideal Score & $\mathbf{0 . 4 0 2 5}$ & \\
\hline
\end{tabular}


Judging from the average of respondent response score, the company performance by using BSC method in Sharia Commercial Banks in Bandung City is in very good category. Then when it is viewed based on dimensions: financial perspective, customer perspective, internal business process perspective and growth and learning process in Sharia Commercial Banks in Bandung City are included in very good category. Although the total average score for company performance is in very good category, there is still a gap from the ideal score of 0.4025 or equivalent to $8.05 \%$. The gap of $8.05 \%$ is a form of quantification of the ideal condition (which is expected) that is if all respondents answered a scale of 5. From the average score of 4.5975 for company performance, the minimum average is 4.38 , while the maximum average is 4.76 . From the table above, it can be seen that the lowest average value is in the dimensions of growth and learning process, so that the improvement process must be carried out to obtain maximum performance in the company, especially Sharia Commercial Banks in Bandung City.

\subsection{The Relation on the Implementation of Good Corporate Governance (GCG) Principles to Company Performance.}

Based on the results of the respondentresponses in a number of Sharia Commercial Banks in Bandung, it was shown that the implementation of GCG principles as they are measured by the dimensions of transparency, accountability, responsibility, independency and fairness was in very good category. Likewise with the results of respondent responses to company performance as they are measured by the BSC method in four dimensions, namely the financial perspective, customer, internal business processes and growth and learning are in very good category. Based on this, it can be said that the better the implementation of GCG principles, it is able to produce

better company performance. The indicators that are used to reflect transparency dimension is the disclosure of financial and non-financial information; involvement of office holders; the existence of a system in internal supervision and control; compliance status, system and implementation of GCG; business objectives and corporate strategy and company vision and mission. The indicators that are used to reflect accountability dimensions are the responsibility for organizational organ that is in accordance with the vision and missionof the bank; responsibility for organizational organ that is in line with the goals and strategiesof the bank; and its responsibility competence. The indicators that are used to reflect responsibility dimension are the principle of prudence and carrying out social responsibility. The indicators that are used to reflect independency dimension are unreasonable domination by stakeholders, unilateral interests and objective decisions. The indicators that are used to reflect fairness dimension are the implementationto theprinciple ofequality and reasonableness; expressing opinions and input for the company and the openness principle.

The indicators that are used to reflect financial perspective dimensions are the increasing of financial returns, sales revenue and lowering costs. The indicators that are used to reflect customer perspective dimensions are the increasing of customer trust, the increased in new products/services and the increased in value which is received by customers. The indicators that are used to reflect the perspective dimensions of internal business processes are the increasing of improvement and the decreasing of non-value-added activities. The indicators that are used to reflect growth and learning perspective dimensions are the increasing of productivity, organizational quality, quality of facilities and infrastructure and quality of management information systems. The following will explain the extent of the relation between the implementation of GCG principles and the company performance as it is measured by BSC method. 
Based on the interview results with management in 9 Sharia Commercial Banks in Bandung city, if the management of Sharia commercial bank is carried out with the principle of responsibility in which the storage and distribution of sharia finance is carried out by taking into account the principles of prudence and responsibility, the customers will increasingly believe to conduct business transactions with sharia banks, because basically the banking business is a trust business. When the customers increasetheir level of trust in the banking system, then at that time, the bank will produce a better level of financial return. This is one proof that the implementation of GCG principles are done very well so that the company performance as it is measured by BSC method will also produce a better level of performance that is measured from a financial and customer perspective. From the results of the subsequent interviews, it is also known when the banking sector carries out the transparency principle as good as possible through disclosure of financial and non-financial information; involvement of office holders; the existence of a system in internal supervision and control; very good compliance status, the stakeholders including the community will be more confident in the security of the funds which they deposit at sharia banks. With the increasing confidence, the community will always continue to increase the deposit of funds in sharia bank so that the level of distribution of funds to sharia banks will continue to increase for the benefit of the people. When the level of funding and financing are equally increasing, the level of financial return which is expected by sharia banks will always be achieved well and in terms of the number of customers will also increase. Based on the description in the discussion, it can be said that the implementation of GCG principles is able to improve company performance as it is measured by BSC method. The better implementation of GCG principles will make the better level of performance that can be achieved by the company, especially the company performance which is measured by BSC method.

The results of this study are supported by various studies that are conducted previously by the researchers such as: Lestari (2013 \& 2015), Ahmed \&Hamdan (2015), Halimatusadiah, et al., (2015), Mustapa, et al., (2015), Kasim (2015), Sanchia\&Zen (2015), Wagana\&Kananja (2015), Pasic, et al., (2016), Ramli, et al., (2016), Alam, et al., (2017), Alobaidi, et al., (2017), Buallay, et al., (2017), Halim, et al., (2017), Khazalia (2017), Galileoni\& Lestari (2017), Uyar, et al., (2017).

\section{Conclusion}

Based on the discussion in the previous chapter, the conclusions are as follows:

1) The implementation of the Good Corporate Governance (GCG) Principles at Sharia Commercial Banks in Bandung City is in very good category. This can be seen from the implementation on the principles of Transparency, Accountability, Responsibility, Independence and Fairness at Sharia Commercial Banks in Bandung City is very good.

2) Company performance which is measured by using the Balanced Score Card (BSC) method at Sharia Commercial Banks in Bandung City is in very good category. Itis known from the achievement of company performance through financial perspective, customer perspective, internal business process perspective and the process of growth and learning at Sharia Commercial Banks in Bandung city which is very good.

3) The relation between the implementation of GCG principles and company performance as it is measured by the BSC method at Sharia Commercial Banks in Bandung City can be proven by one of 
them when Sharia Commercial Banks apply the principle of responsibility in banking management very well, the level of company performance one of which is measured by financial and customer perspectives also increases. Because the increased level of customer trust which is caused by the banking business is carried out responsibly so that Shariacommercial banks also get an increased level of financial return. Finally, it can be said that there has been a very close relation between the implementation of GCG principles and company performance as it is measured by the BSC method.When the GCG principles are implemented very well, the company performance which is measured by using the BSC method will be also achieved very well.

\section{References}

Adi, Tri Wahyu., Suhadak.,Handayani, Siti Ragil and Rahayu, Sri Mangesti. 2013. The Influence of Corporate Governance and Capital Structure on Risk, Financial Performance and Firm Value: Study on The Mining Company Listed in Indonesia Stock Exchange in 2009-2012. European Journal of Business and Management, Vol. 5 No.29, 2013.

Aggarwal, Priyabka. 2013. Impact of Corporate Governance on Corporate Financial Performance. IOSR Journal of Business Management, eISSN: 2278-487X, p. ISSN: 2319-7668, Vol.13, Issue 3 (Sep-Oct 2013).

Ahmed, Esra and Hamdan, Allam. 2015. The Impact of Corporate Governance on Firm Performance: Evidence from Bahrain Stock Exchange. European Journal of Business and Innovation Research, Vol. 3 No.5 December, 2015.

Alam, Rafiqul Mohammed., Akhter, Fahmida. 2017. Impact of Corporate Governance on Performance of Commercial Banks in Bangladesh. The Cost And Management, Volume-45, No.4, July-Agust, 2017. ISSN: 1817-5090.

Alobaidi, F., Aloqab A and Raweh B. 2017. Corporate Governance in Banking Sector: Case Study of Yemen. International Journal of Economics, Commerce and Management, Vol. V, Issue 12, Dec 2017.

Buallay, Amina.,Hamdan, Alam., Zureigat, Qasim. 2017.Corporate Governance and Firm Performance: Evidence from Saudi Arabia. Australasian Accounting, Business and Finance Journal, Vol 11 Issue 1.

El Gabasi, A.H.B., Kertahadi and Firdausi, N. 2014. An Analysis of Corporate Governance and Its Impact on the Firm's Financial Performance in Libya: (A Study in ENI Oil and Gas Company). IOSR Journal of Business and Management, Vol. 16, Issue 7, July 2014.

Fadilah, Sri. 2011. PengaruhImplementasiPengendalian Intern, BudayaOrganisasidan TQM dalamPenerapan Good Governance danImplikasinyaTerhadapKinerja Perusahaan DenganKepercayaanKonsumenSebagaiVariabel Intervening (StudipadaLembagaAmil Zakat Seluruh Indonesia). Indonesian Journal of Economics and Business.

Fidanoski, Filip.,Mateska, Vesna and Simeonouski, Kiril. 2013. Corporate Governance and Bank Performance: Evidence from Macedonia. Munich Personal RePEc Archive, Mei 2013.

Galilieoni, Gintan Delta dan Lestari, Rini. 2017. PengaruhPenerapan Good Corporate Governance terhadapPenilaianKinerja Perusahaan. Proceeding: $1^{\text {st }}$ National Seminar on Small Medium Enterprises "Towards the Self Reliance of Micro, Small and Medium Enterprises in Indonesia. ISBN: 978-602-764247-8.

Halim, E. H., Mustika G., Sari, R N., Anugerah, R and Mohd-Sanusi, Z. 2017. Corporate Governance Practices and Financial Performance: The mediating effect of risk management committee at manufacturing firms. Journal of International Studies, 10(4), 272-289.

Halimatusadiah, E., Sofianty D, and Ermaya, H N. 2015. Effect of The Implementation of Good Corporate Governance on Profitability. European Journal of Business and Innovation Research, Vol. 3, No. 4, pp 19-35, September, 2015.

Kaplan, R. S., and Nagel M. E. 2004.Improving Corporate Governance with the Balanced Scorecard. Division of Research: Harvard Business School.

Kasim, E. Y. 2015. Effect of Implementation of Good Corporate Governance and Internal Audit of The Quality of Financial Reporting and Implications of Return of Shares. International Journal of Scientific \& Technology Research, Volume 4, Issue 09, September 2015.

Khazalia, Nino Oleg Deev. 2017. Corporate Governance, Social Responsibility and Financial Performance of European Insurers. ACTA, Volume 65, No.6, 2017.

Lestari, Rini. 2015. The Influence of Manager Competence on The Quality of Management Accounting Information System and its implication on The Quality of Management Accounting Infromation. Serials 
Publications. International Journal of Applied Business and Economic Research Vol.13 No.6, 2015 (indexed Scopus).

2013. PengaruhManajemenRisikoterhadapKinerjaOrganisasi (StudiPada Dana PensiunPemberiKerja di Wilayah Jabar-Banten.JurnalRisetAkuntansidanBisnis, Vol 13 Iss 2 pp 131-151.

Makki, Muhammad Abdul Majid and Lodhi, Sulaeman Aziz. 2013. Impact of Corporate Governance on Financial Performance. Pakistan Journal of Social Sciences (PJJS), Vol.33, No. 2 (2013), pp. 265-280.

Masyarakat Anti Korupsi Indonesia (MAKI).2018. PembiayaanFiktifpada Bank SyariaMandiri.Melalui, http://m.cnnindonesia.com $[10 / 8 / 18]$.

Mudashiru, A., Bakare, I. A. O., Babatunde, Y and Ishmael, O. 2014. Good Corporate Governance and Organisational Performance: An Empirical Analysis. International Journal of Humanities and Social Science, Vol. 4, No. 7(1), May 2014.

Mustapa, IfaRizad., Ghazali, NazliAinunMohd., Mohamad, Muslim HarSani. 2015. The Influence of Corporate Governance and Organizational Capacity on The Performance of Malaysian Listed Companies. Mediteranean Journal of Social Sciences.MCSR Publishing, Rome-Italy, Vol. 6. No. 351, May, 2015.

Nazir,Moh. 2011. Metode Penelitian. Bogor: Ghalia Indonesia.

Otoritas Jasa Keuangan. 2017. Buku Statistik Perbankan Syariah.

Pasic, P., Bratina, B and Festic, M. 2016.Corporate Governance of Banks in Poland and Slovenia.NASE GOSPODARSTVO/OUR ECONOMY, Vo. 62 No. 3, September 2016.

POJK. No.4/POJK.03/2015. Pedoman Tata Kelola Bank Umum.

Ramli, AnisJuliana.,Ramli, Ismail Mohd. 2016. Corporate Governance and Corporate Performance of Malaysian Companies: Examining from on Islam Perspective. Procedia Economics \& Finance.

Sanchia, M. I and Zen, T S. 2015. Impact of Good Corporate Governance on Corporate Performance.International Journal of Management and Applied Science, Vol 1, Issue 9, Oct, 2015.

Setiyawati, H \& Nengzih, M. 2014.The Effect of the Implementation of Good Corporate Governance Principles and the Effectiveness of Internal Control System Disclosure of Environmental Accounting and Its Implications on the Company Performance (Studies in State-Owned and Private Hospitals in Jakarta).Research Journal of Finance and Accounting, Vol. 5, No. 24, 2014.

Siallagan, H \&Januarti, I. 2014. The Effect of Good Corporate Governance Implementation and Proportions of State Ownership on Banking Firms Market Value.International Journal of Business, Economics and Law, Vol.5, Issue 1 (Dec).

Susanto. 2016. The influence of accounting information system quality to accounting information quality and its implication on the good study program governance. International Business Management, ISSN: 1993-5250.

Todorovic, I. 2013. Impact of Corporate Governanceon Performance of Companies.Montenegrin Journal of Economics, Vol. 9, no. 2, May, 2013.

Tornyeva, Kingsley.,Wereko, Theophilus. 2012. Corporate Governance and Firm Performance Evidence from the Insurance Sector of Ghana. Eurpoean Journal of Business and Management.

Uyar, Ali.,Gungormus, H. Ali., Kuzey, Cemil. 2017. Impact of the Accounting Information System on Corporate Governance: Evidence from Turkish Non-Listed Companies. Australasian Accounting, Business and Finance Journal, Vol.11, Issue 1.

Wagana, Duncan and Kananja, Kabare. 2015. The Influence of Corporate Governance on Corporate Performance Among Manufacturing Firms in Kenya: A Theoretical Model. International Journal of Academic Research in Business and Social Sciences, April 2015, Vol.5, No.4, ISSN: 2222-6990

Yesser, RafiqueQaiser., Entebang, Harry.,Mansor, Abu Shazali. 2011. Corporate Governance and Firm Performance in Pakistan: The Case of Karachi Stock Exchange (KSE). Journal of Economic and International Finance, Vol.3 (8) August, 2011.

Zarkasyi, Wahyudin. 2008. Good Corporate Governance padaBadan Usaha Manufaktur,PerbankandanJasaKeuanganLainnya. Bandung: CV Alfabeta. 